\title{
An insight into the antibiofilm properties of Costa Rican stingless bee honeys
}

Objective: There is an increasing search for antibiofilm agents that either have specific activity against biofilms or may act in synergy with antimicrobials. Our objective is to examine the the antibiofilm properties of stingless bee honeys.

Method: Meliponini honeys from Costa Rica were examined along with Medihoney as a reference. All honeys were submitted to a screening composed of minimum inhibitory concentration, inhibition of biofilm formation and biofilm destruction microplate-based assays against a Staphylococcus aureus biofilm forming strain. Dialysis led to the isolation of an antibiofilm fraction in Tetragonisca angustula honeys. The honey antibiofilm fraction was evaluated for protease activity and for any synergistic effect with antibiotics on a Staphylococcus aureus biofilm. The active fraction was then separated through activity guided isolation techniques involving SDS-PAGEs, anion exchange and size exclusion fast protein liquid chromatographies. The fractions obtained and the isolated antibiofilm constituents were tested for amylase and DNase activity. Results: A total of 57 Meliponini honeys from Costa Rica were studied in this research. The honeys studied belonged to the Tetragonisca angustula $(n=36)$ and Melipona beecheii $(n=21)$ species. Costa Rican Tetragonisca angustula honeys can inhibit the planktonic growth, biofilm formation, and are capable of destroying a Staphylococcus aureus biofilm. The antibiofilm effect was observed in the protein fraction of Tetragonisca angustula honeys. The biofilm destruction proteins allowed ampicillin and vancomycin to recover their antimicrobial activity over a Staphylococcus aureus biofilm. The antibiofilm proteins are of bee origin, and their activity was not due to serine, cysteine or metalloproteases. There were 2 proteins causing the antibiofilm action; these were named the Tetragonisca angustula biofilm destruction factors (TABDFs). TABDF- 1 is a monomeric protein of approximately $50 \mathrm{kDa}$ that is responsible of the amylase activity of Tetragonisca angustula honeys. TABDF-2 is a protein monomer of approximately $75 \mathrm{kDa}$.

Conclusion: Tetragonisca angustula honeys from Costa Rica are a promising candidate for research and development of novel wound dressings focused on the treatment of acute and chronic Staphylococcus aureus biofilm wound infections.

Declaration of interest: The O \& O Office of Utrecht University and the Scholarships Office of Universidad Nacional of Costa Rica solely provided financial support for this study. The authors declare there are no conflicts of interest.

\section{Tetragonisca angustula $\bullet$ antibiofilm $\bullet$ Staphylococcus aureus $\bullet$ Melipona beecheii $\bullet$ stingless bee honey}

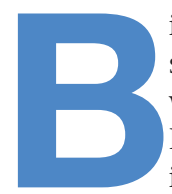
iofilms constitute the predominant living strategy that bacteria adopt in order to withstand diverse and harsh environments. ${ }^{1}$ It is estimated that $80 \%$ of all microbial infections involve biofilms. ${ }^{2,3}$

Biofilms are composed of sessile cells embedded in an extracellular polymeric substance (EPS) matrix. ${ }^{1,4,5}$ Planktonic bacteria can be easily controlled by the host's immunity, antibiotics, and antiseptics. ${ }^{1,6,7}$ The bacteria inside the biofilm matrix are the key to survival in adverse environments, ${ }^{1,7}$ and are protected from the host's

*L.G. Zamora, ${ }^{1,2}$ Microbiologist, Coordinator of the Microbiology and Medicinal Chemistry Program; C.J. Beukelman, ${ }^{1}$ PhD, Associate Professor; A.J.J. van den Berg, ${ }^{1} \mathrm{PhD}$, Associate Professor; P.C. Aerts, ${ }^{3}$ Senior Technician; H.C. Quarles van Ufford, ${ }^{1}$ Research and Education Assistant; R. Nijland, ${ }^{3,4} \mathrm{PhD}$, Assistant Professor, Coordinator of the Bacteriology Group; M.L. Arias, ${ }^{5} \mathrm{MSc}$, Coordinator of the Laboratory of Food Microbiology

*Corresponding author e-mail: luis.zamora.fallas@una.cr

1 Medicinal Chemistry and Chemical Biology Program, Department of Pharmaceutical Sciences, Faculty of Science, Utrecht University. David de Wiedgebouw, P. O. B. 80082, 3508 TB Utrecht,

The Netherlands. 2 Centro de Investigaciones Apícolas Tropicales, Universidad Nacional. P. O. Box 475-3000 Heredia, Costa Rica. 3 Medical Microbiology, University Medical Center Utrecht, P. O. B. 85500,3508 GA Utrecht, The Netherlands. 4 Laboratory of Phytopatology, Wageningen University. P. O. Box 16, 6700 A A Wageningen, The Netherlands. 5 Facultad de Microbiología, Universidad de Costa Rica. P. O. Box 2060-1000 San José, Costa Rica. immune system. An acute wound infection follows a type Th2 immune response. ${ }^{7,8,9}$ Although innate immunity avidly recognises and reacts to the biofilm matrix constituents, ${ }^{8,10}$ polymorphonuclear leucocytes cannot eliminate a biofilm through phagocytosis. ${ }^{4,5,8}$ This leads to phagocytic enzymes, and reactive oxygen species to be released in the intercellular medium. Consequently, the immune response damages healthy neighbouring tissue, prolongs inflammation, and leads to a delayed healing or a chronic process. $2,4,6,8,11$

Despite the fact that most antibiotics and antiseptics can diffuse inside the biofilm matrix channels, biofilms can be non-responsive to antibiotic therapy and antiseptic treatments. $2,4,7,11,12,15$ The metabolic heterogeneity of the bacterial population inside the EPS matrix, along with the presence of persister cells allow biofilms to survive. Moreover, cells in a latent state can regain metabolic activity once in more favourable conditions and quickly reestablish biofilm populations. ${ }^{2,5,7}$ Hence, biofilms are considered the main reason for antimicrobial resistance in the clinical setting. ${ }^{3,11}$

Biofilms can act as reservoir for infection, $, 13,8,16,17$ 
and an estimated $60 \%$ of hospital-acquired infections are biofilm related. ${ }^{7,16,18}$ In addition, biofilms are associated to chronic wound infections and their inability to heal. ${ }^{2,4,11,19-21}$ Hence, there is an increasing search for antibiofilm agents that either have specific activity against biofilms or may act in synergy with antimicrobials. $6,7,12-14$

Honey, a more than four millennia-old therapy for wound healing has had resurgence of interest. ${ }^{22-27}$ Medicinal honey is produced in Australia and New Zealand; honeybees (Apis mellifera) collect the nectar of the manuka tree (Leptospermum scoparium) to produce manuka honey. ${ }^{28-30}$ Medihoney (DermaSciences, Inc.), a manuka honey-based wound treatment has proven clinical efficacy against antibiotic resistant microorganisms, ${ }^{29,31}$ and in 2008 Medihoney received the US Food and Drug Administration (FDA) approval for use as a wound dressing. ${ }^{26,32}$ In addition, recent investigations report that Medihoney has in vitro inhibitory activity against Pseudomonas aeruginosa, Streptococcus pyogenes and Staphylococcus aureus biofilms. ${ }^{33-36}$

Mesoamerican stingless bees (family Apidae, tribe Meliponini) produce honeys that have a long dated ethnopharmacological history. ${ }^{38-40}$ The ancient Maya and Aztec cultures started the keeping of stingless bees (meliponiculture) and used the honey for several medical applications; among them, wound healing. ${ }^{41,42}$ Meliponiculture, and the use of Meliponini honeys as wound dressings are still part of Costa Rica's traditions and folk medicine. ${ }^{38,40,43,44}$

Recently, investigations on the medicinal properties of Costa Rican stingless bee honeys have revealed that these honeys possess high microbiological quality. The later was confirmed by the absence of pathogens, and low microbial counts that allow compliance with the European Pharmacopoeia's acceptance criteria for microbiological quality of non-sterile substances for pharmaceutical use. ${ }^{23}$ In addition, these Meliponini honeys reported in vitro antioxidant capacities and immunomodulatory activities (that are relevant to wound healing) with no statistical significant differences to Medihoney. ${ }^{45}$ Furthermore, stingless bee honeys proceeding from Costa Rica have broadspectrum antimicrobial activity. These honeys were active against type culture microbial strains of clinical relevance for the wound healing practice. ${ }^{23,44-46}$ Finally, Costa Rican Meliponini honeys reported inhibitory action over antibiotic-resistant isolates of Staphylococcus aureus and Pseudomonas aeruginosa obtained from infected hospital patients. ${ }^{47}$

To our knowledge, this is the first article to examine the antibiofilm properties of stingless bee honeys using Staphylococcus aureus biofilm microplate-based assays and activity guided isolation techniques.

\section{Materials and methods}

Sample collection

Meliponini honeys, from the Tetragonisca angustula and
Melipona beecheii species, were bought directly from keepers in Costa Rica, from areas where meliponiculture is practiced. These samples have been assessed previously for density, percentage of humidity, microbiological safety, botanical origin, antimicrobial activity, antioxidant capacity, and immunomodulatory activity. $., 23,44-47$

A manuka honey-based wound dressing (Medihoney) was used as reference standard. The manufacturer states this dressing consists of $100 \%$ active Leptospermum honey (medical grade honey).

\section{Biofilm forming bacteria}

A Staphylococcus aureus biofilm forming strain (BMA/ FR/0.32/0074) was used. The bacteria were isolated from cow mastitis. These grow as biofilm in polystyrene microplates when cultivated at $35^{\circ} \mathrm{C}$ in tryptic soya broth (TSB) (Oxoid, UK) enriched with $0.25 \%$ (mass/volume) glucose (TSBG). ${ }^{48}$

\section{Preparation of honey solutions}

All the honey solutions for the minimum inhibitory concentration (MIC) and biofilm tests were prepared in TSBG broth. For the preparation of the test solutions of each sample and reference, the individual density of every honey was taken into account, as a means of attaining comparable results since Meliponini honeys present higher water content values than Apis mellifera honeys. ${ }^{23}$

\section{Minimum inhibitory concentration (MIC) assays}

The antimicrobial activity of the Meliponini honeys and Medihoney against a Staphylococcus aureus biofilm was determined with a microplate MIC assay performed as previously described. ${ }^{23}$ In final volume of $200 \mu$ l per well, $1.0 \times 10^{6}$ colony forming units (CFU)/well Staphylococcus aureus were added to the TSBG broth. Aseptic technique was maintained during all the steps of the assays.

\section{Inhibition of biofilm formation}

The inhibitory action of honeys over the Staphylococcus aureus biofilm formation was determined by a microplate method based on the procedure described by Hensen. ${ }^{48}$ An overnight culture $\left(35^{\circ} \mathrm{C}, 24\right.$ hours $)$ of Staphylococcus aureus was prepared on blood agar. This culture was used to prepare an overnight culture in TSBG broth, which was then diluted 1:50 in TSBG and used for the biofilm test.

Serial dilution of three aliquots $(200 \mu \mathrm{l})$ of honey test solutions were made in TSBG into a sterile round bottom microplate (Corning Inc., US). We used $100 \mu$ l of TSBG as a blank. Staphylococcus aureus suspension $\left(1.0 \times 10^{6} \mathrm{CFU} /\right.$

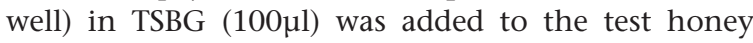

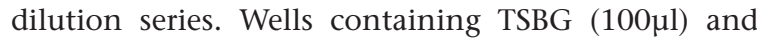
Staphylococcus aureus culture $(100 \mu \mathrm{l})$ were used as control for biofilm formation (100\% biofilm). The microplate was covered and incubated $\left(35^{\circ} \mathrm{C}, 24\right.$ hours) in a gravimetric airflow incubator (Digisystem Laboratory Instruments Inc., Taiwan). 
After incubation, the broth and the planktonic bacteria were removed by inverting the microplate over a bucket with disinfectant and then placing the plate upside down on absorbent paper. The microplate wells were washed twice with demineralised water, the plate was then dried on absorbent paper. The biofilm was then fixed to the microplate using a solution of $0.1 \mathrm{M} \mathrm{HCl}$ dispensed in each well and the plate was incubated at room temperature $\left(23^{\circ} \mathrm{C}, 90\right.$ minutes). The $\mathrm{HCl}$ solution was removed and the plate was dried. The biofilm was stained by adding a solution of $0.1 \%$ (mass/volume) safranin to each well. The plate was incubated at room temperature $\left(23^{\circ} \mathrm{C}\right.$, 60 minutes), after which, the excess of safranin was removed. The wells were washed four times $(200 \mu \mathrm{l}$ demineralised water) and the plate was dried. Subsequently, $0.2 \mathrm{M} \mathrm{NaOH}(125 \mu \mathrm{l})$ was added to the wells, the lid and bottom borders of the plate were sealed with parafilm and the plate was then incubated $\left(57^{\circ} \mathrm{C}, 60\right.$ minutes $)$.

The content of each well was mixed with a micropipette and $100 \mu \mathrm{l}$ of every well were transferred to a flat bottom microplate (Greiner Bio-One $\mathrm{GmbH}$, Germany). The absorbance of the test solution at $540 \mathrm{~nm}$ was measured in a Multiskan Spectrum microplate reader with SkanIT DDE software (Thermo Scientific, Finland). Biofilm inhibition was calculated as the concentration capable of achieving a $50 \%$ inhibition (biofilm inhibition $\mathrm{IC}_{50}$ ). The inhibitory effect on biofilm was expressed in a concentration-dependent manner. All conditions were subject of three separate analyses.

\section{Biofilm destruction assay}

A biofilm culture was prepared in a sterile round bottom microplate. The wells of two columns were filled with Staphylococcus aureus suspension $(100 \mu \mathrm{l}) 2.0$ $\left.\mathrm{x} 10^{6} \mathrm{CFU} / \mathrm{ml}\right)$ in TSBG, in another column, TSBG broth $(100 \mu \mathrm{l})$ was dispensed in the wells as a blank. The lid and bottom borders of the microplate were sealed with parafilm, and the culture was incubated $\left(35^{\circ} \mathrm{C}, 24\right.$ hours). In another sterile round bottom microplate, sample serial dilutions and blanks were prepared as previously described and $100 \mu$ l of the sample dilutions and controls were added to the biofilm culture plate. The microplate assay was sealed with parafilm and incubated for 24 hours $\left(35^{\circ} \mathrm{C}\right)$. After incubation, the broth and planktonic bacteria were removed and the plates were processed as described in for the biofilm formation assay.

The ability of samples to disrupt a previously formed Staphylococcus aureus biofilm was calculated as the concentration capable of destroying $50 \%$ of the biofilm (biofilm destruction $\mathrm{IC}_{50}$ ). Every sample and the reference were subject of three separate analyses.

The effects of ampicillin $(5 \mu \mathrm{g} / \mathrm{ml})$ (Sigma A9393) and of vancomycin $(500 \mu \mathrm{g} / \mathrm{ml})$ (Sigma V2002) on biofilm forming Staphylococcus aureus in TSBG were tested in the MIC, biofilm formation and biofilm destruction assays.

\section{Activity guided isolation of organic fractions by Soxhlet extraction}

Tetragonisca angustula honey (35g) was dissolved in demineralised water $(35 \mathrm{ml})$ and transferred into the extraction thimble of the Soxhlet extractor. Next, 100ml of the extraction solvent were added inside the thimble, and another $200 \mathrm{ml}$ dispensed in the Soxhlet apparatus flask. The extraction procedures were performed with solvents of increasing polarity (petroleum ether, diethyl ether, and ethyl acetate). Each solvent was refluxed for 8 hours, and the temperature of every extraction corresponded to the boiling point of each of the solvents applied. After every extraction, the solvent was removed from the fraction obtained with the aid of a rotary evaporator. At the end of the Soxhlet extractions, the remaining water-soluble fraction was freeze dried. All the fractions obtained were tested in the MIC, biofilm formation and biofilm destruction assays.

\section{Activity guided isolation: concentration of the honey proteins fraction by dialysis}

Tetragonisca angustula honey (50g) dissolved in demineralised water $(100 \mathrm{ml})$ was dispensed in three $50 \mathrm{ml}$ centrifuge tubes (Corning, US), centrifuged (2500rpm, 5 minutes), and the supernatant was removed and sterilised by filtration through a $0.220 \mu \mathrm{m}$ pore vacuum filter (Corning, US). The honey solution was kept in a sterile glass bottle before dialysis.

A dialysis membrane (Medicell International LTD., UK), with a $12-14 \mathrm{kDa}$ pore, a diameter of $1 \frac{114}{4}$ inches and a width of $50-54 \mathrm{~nm}$, was filled with the sterile honey solution and placed inside a pitcher filled with demineralised water (51). The water was changed 3 times a day, the dialysis was performed at $4^{\circ} \mathrm{C}$, under constant stirring, and for a period of 144 hours. During this process the dialysate was stored. Afterwards, a 11 sample of the dialysate and the content inside the membrane were freeze dried. A $1 \mathrm{mg} / \mathrm{ml}$ solution of the honey proteins fraction $(\mathrm{HPF}>12 \mathrm{kDa})$ and the dialysate were prepared in TSBG under sterile conditions and tested in the MIC, biofilm formation and biofilm destruction assays.

Separation of the honey protein antibiofilm constituents from HPF>12kDa: anion exchange chromatography

$\mathrm{HPF}>12 \mathrm{kDa}(200 \mathrm{mg})$ was dissolved in $4 \mathrm{ml}$ of Tris- $\mathrm{HCl}$ $20 \mathrm{mM}$ buffer ( $\mathrm{pH} 7.5$ ), and passed through a $0.22 \mu \mathrm{m}$ syringe filter. This solution $(2 \mathrm{ml})$ was injected into an Äkta Fast Protein Chromatography System (FPLC) (GE Healthcare Bio-Sciences AB, Sweden) coupled to a HiTrap Q XL $5 \mathrm{ml}$ sepharose ion exchanger column (GE Healthcare Bio-Sciences AB, Sweden). The FPLC system was set to a flow rate of $5 \mathrm{ml} / \mathrm{min}$, Tris- $\mathrm{HCl} 20 \mathrm{mM}$ buffer ( $\mathrm{pH}$ 7.5) was used as mobile phase (Buffer A), absorbance was monitored at $280 \mathrm{~nm}$, and proteins were eluted from the column using a linear $\mathrm{NaCl}$ gradient $(0-1.0 \mathrm{M})$ in Tris$\mathrm{HCl} 20 \mathrm{mM}$ buffer (Buffer B). Fractions of $2 \mathrm{ml}$ were collected and grouped into pools according to the peaks obtained through the chromatography. The fraction pools were submitted to dialysis (as described previously) 
Table 1. MIC, biofilm formation and biofilm destruction results for Meliponini honeys, Medihoney and antibiotics. Results are presented as median values and percentage of active samples per bee species

\begin{tabular}{|c|c|c|c|c|c|c|}
\hline Honey source & MIC & $\%$ active & $\begin{array}{l}\text { Biofilm } \\
\text { formation }\end{array}$ & $\begin{array}{l}\% \\
\text { active }\end{array}$ & $\begin{array}{l}\text { Biofilm } \\
\text { destruction }\end{array}$ & $\%$ active \\
\hline Tetragonisca angustula & $98 \mathrm{mg} / \mathrm{ml}$ & 100 & $22 \mathrm{mg} / \mathrm{ml}$ & 100 & $32 \mathrm{mg} / \mathrm{ml}$ & $94^{*}$ \\
\hline Melipona beecheii & $96 \mathrm{mg} / \mathrm{ml}$ & 100 & $52 \mathrm{mg} / \mathrm{ml}$ & 100 & $28 \mathrm{mg} / \mathrm{ml}$ & 29 \\
\hline Reference Medihoney & $204 \mathrm{mg} / \mathrm{ml}$ & - & $55 \mathrm{mg} / \mathrm{ml}$ & - & NE & - \\
\hline Antibiotics & MIC & & \multicolumn{2}{|c|}{ Biofilm formation } & \multicolumn{2}{|c|}{ Biofilm destruction } \\
\hline Ampicillin & $125 \mathrm{ng} / \mathrm{ml}$ & & $6 \mathrm{ng} / \mathrm{ml}$ & & NE & \\
\hline Vancomycin & $63 \mu \mathrm{g} / \mathrm{ml}$ & & $400 \mathrm{ng} / \mathrm{ml}$ & & NE & \\
\hline
\end{tabular}

for 24 hours, and later freeze dried. Solutions of every pool $(100 \mu \mathrm{g} / \mathrm{ml})$ were prepared in TSBG under sterile conditions and tested in the biofilm formation and destruction assays. Each sample was subjected to three individual tests per assay. Finally, the fractions active in both biofilm formation and destruction assays (Fplc 1, Fplc 3) were subjected to the next purification steps.

Separation of Fplc 1 by size exclusion chromatography The fraction Fplc $1(17.7 \mathrm{mg})$ was dissolved in sodium and magnesium PBS $(500 \mu \mathrm{l}$; DPBS), and filtered through a $0.22 \mu \mathrm{m}$ SpinX centrifuge tube filter (Corning). The Fplc 1 solution ( $400 \mu l)$ was injected into an Äkta FPLC System coupled to a Superdex HiLoad 75 26/60 preparative grade size exclusion chromatography column (GE Healthcare). The FPLC system was set to a flow rate of $2.5 \mathrm{ml} / \mathrm{minute}$, DPBS was used as a mobile phase, absorbance was monitored at $280 \mathrm{~nm}$, and $2 \mathrm{ml}$ fractions were collected. Before gathering the fractions into pools, $15 \mu \mathrm{l}$ of the fractions that contained the tip of each peak of the chromatogram were put through SDS-PAGEs. The fractions were grouped into pools according to the peaks obtained through the chromatography. The pools were dialysed for 24 hours and freeze dried. All samples were tested in the biofilm formation and destruction assay. Each sample was subject of three individual tests per assay.

Table 2. MIC, biofilm formation (BF) and biofilm destruction (BD) results obtained for dialysis fractions from a Tetragonisca angustula honey

\begin{tabular}{|lccc|}
\hline & MIC & BF & BD \\
\hline $\begin{array}{l}\text { Tetragonisca angustula honey } \\
\text { Sample \#29 }\end{array}$ & $98 \mathrm{mg} / \mathrm{ml}$ & $21 \mathrm{mg} / \mathrm{ml}$ & $34 \mathrm{mg} / \mathrm{ml}$ \\
\hline $\begin{array}{l}\text { Dialysate } \\
\text { HPF>12 kDa }\end{array}$ & $\mathrm{NI}$ & $\mathrm{NI}$ & $\mathrm{NE}$ \\
\hline $\begin{array}{l}\text { HPF>12kDa-honey protein fraction }>12 \mathrm{kDa} \text {; MIC-minimum inhibitory concentration; } \mathrm{NI}-\mathrm{no} \text { inhibition } \\
\text { under the conditions tested; NE-no effect over the Staphylococcus aureus biofilm under the } \\
\text { conditions tested }\end{array}$ & $18 \mu \mathrm{g} / \mathrm{ml}$ & $10 \mu \mathrm{g} / \mathrm{ml}$ \\
\hline
\end{tabular}

Separation of Fplc 3 by size exclusion chromatography Fplc $3(50 \mathrm{mg})$ of fraction were dissolved in $1.250 \mathrm{ml}$ of DPBS and filtered through a $0.22 \mu \mathrm{m}$ SpinX centrifuge tube filter. The Fplc 3 solution was injected into an Äkta FPLC System coupled to a Superdex HiLoad 200 26/60 GL column. The FPLC chromatography, dialysis, and freezedrying of pools were performed under the same conditions described for the Fplc 1 separation. Before gathering the fractions into pools, $15 \mu$ l of each were put through SDS-PAGEs. In addition, 50 $\mu$ l of each fraction were tested in the biofilm destruction assay. Likewise, $50 \mu 1$ of DPBS were tested as a control. In this particular case, besides the chromatogram, the fraction pools were prepared taking into consideration SDS-PAGE and BD test results. Finally, the fractions obtained were tested in the biofilm formation and destruction assay. Each sample was subject of three individual tests per assay.

\section{SDS-PAGE}

SDS-PAGEs were performed in non-denaturing and denaturing conditions with dithiothreitol (DTT). InstantBlue (C.B.S. Scientific, US) was used as SDS remover and stain. This method was described previously. ${ }^{49}$

\section{Characterisation of HPF $>12 \mathrm{kDa}$ and active fractions:} effect of protease inhibitors

$\mathrm{BF}$ and $\mathrm{BD}$ assays were prepared with $\mathrm{HPF}>12 \mathrm{kDa}$ in the presence of protease inhibitors to test if the HPF $>12 \mathrm{kDa}$ contained protease activity. Phenylmethanesulfonyl fluoride (PMSF) (Sigma, US), a serine protease inhibitor, was dissolved in TSBG (final concentration: $10 \mathrm{mM}$ ), one tablet of cOmplete Mini protease inhibitor cocktail (Roche, Germany) was dissolved in TSBG $(10 \mathrm{ml})$.

A solution of the HPF $>12 \mathrm{kDa}(2 \mathrm{mg} / \mathrm{ml})$ in TSBG was serially diluted in a sterile round bottom microplate. The protease inhibitor was added to the dilution series. For the biofilm formation tests Staphylococcus aureus suspension ( $100 \mu \mathrm{l}$ in TSBG, $1.0 \times 10^{6} \mathrm{CFU} /$ well) was added to the test dilution series. For the biofilm destruction assay $100 \mu \mathrm{l}$ of each of the dilutions were dispensed over a biofilm microplate culture. The effect of the protease inhibitors alone on the biofilm was used as a control. 


\section{Effect of HPF $>12 \mathrm{kDa}$ and antibiotics over a Staphylococcus aureus biofilm}

Ampicillin $(1 \mathrm{mg} / \mathrm{ml})$ and vancomycin $(1 \mathrm{mg} / \mathrm{ml})$ were prepared in TSBG. The antibiotic solutions were serially diluted in a sterile round bottom microplate with $100 \mu \mathrm{l}$ of TSBG enriched with $\mathrm{HPF}>12 \mathrm{kDa}(200 \mu \mathrm{g} / \mathrm{ml})$. Immediately, $100 \mu \mathrm{l}$ of every dilution was dispensed over a biofilm microplate culture, including three controls. The final volume per well was $200 \mu \mathrm{l}$. The assay was incubated at $35^{\circ} \mathrm{C}$ for 24 hours. Next, $50 \mu \mathrm{l}$ of every well of the dilution series were seeded on blood agar and incubated for 24 hours $\left(35^{\circ} \mathrm{C}\right)$. The lowest antibiotic concentration that produced absence of Staphylococcus aureus growth was considered the MIC value. In addition, the microplate assay was processed as described in order to confirm biofilm destruction and the performance of controls. Each antibiotic was subject of three individual tests.

\section{DNAse assay}

$\mathrm{HPF}>12 \mathrm{kDa}$ and fractions separated through activityguided isolation were tested for DNase activity according to the method described by Nijland et al. ${ }^{50}$ In brief, the fractions were incubated with a purified plasmid DNA $\left(37^{\circ} \mathrm{C}, 30\right.$ minutes). DNase type I was used as a control. EDTA, which inactivates metal-ion dependent DNases like DNase type I, was added to another set of samples before incubation with plasmids. All the tests were run on a $1 \%$ agarose gel containing ethidium bromide to visualise DNA degradation.

\section{Amylase test}

$\mathrm{HPF}>12 \mathrm{kDa}$ and fractions separated through anion exchange and size exclusion chromatography were tested for amylase activity. The starch and iodine solutions for this assay were prepared as described by Bogdanov et al. ${ }^{51}$ A solution of $1 \mathrm{mg} / \mathrm{ml}$ of $\alpha$-amylase (Sigma A3176, US) in demineralised water was prepared as reference. We dispensed $100 \mu \mathrm{l}$ of the sample or reference in two wells of a flat bottom microplate and serially diluted with $50 \mu \mathrm{l}$ of demineralised water. Next, $50 \mu$ l of the starch solution were delivered in all the wells, the assay was incubated for 30 minutes $\left(40^{\circ} \mathrm{C}\right)$. Then, $50 \mu \mathrm{l}$ of the iodine solution were added to the test wells and absorbance was determined at $660 \mathrm{~nm}$ in a Multiskan Spectrum microplate reader. The blank absorbance was subtracted of every test readings, and a graph of absorbance versus concentration of sample was prepared using Microsoft Excel (Microsoft, US).

\section{Statistical analyses}

The descriptive statistics (percentages, mean and median values) and the statistical inference based on two samples (difference of proportions) between the percentages of biofilm destruction active samples per bee species were done with InfoStat Software (InfoStat Group, Universidad Nacional de Córdoba, Argentina).

\section{Results}

A total of 57 Meliponini honeys were bought directly
Table 3. Biofilm formation (BF) and biofilm destruction (BD) results for the honey protein fraction $>12 \mathrm{kDa}$ in presence of protease inhibitors

\begin{tabular}{|lll|}
\hline Sample & BF & BD \\
\hline HPF>12kDa & $23 \mu \mathrm{g} / \mathrm{ml}$ & $17 \mu \mathrm{g} / \mathrm{ml}$ \\
\hline $\begin{array}{l}\mathrm{HPF}>12 \mathrm{kDa}+ \\
10 \mathrm{mM} \text { PMSF }\end{array}$ & $29 \mu \mathrm{g} / \mathrm{ml}$ & $18 \mu \mathrm{g} / \mathrm{ml}$ \\
\hline $\begin{array}{l}\mathrm{HPF}>12 \mathrm{kDa}+ \\
\text { cOmplete protease mix }\end{array}$ & $16 \mu \mathrm{g} / \mathrm{ml}$ & $16 \mu \mathrm{g} / \mathrm{ml}$ \\
\hline $10 \mathrm{mM}$ PMSF & $\mathrm{NI}$ & $\mathrm{NE}$ \\
\hline $\begin{array}{l}\text { cOmplete protease mix } \\
\text { HPF>12kDa-honey protein fraction }>12 \mathrm{kDa} \text {; NI-no inhibition under the } \\
\text { conditions tested; NE-no effect over the Staphylococcus aureus biofilm } \\
\text { under the conditions tested; PMSF- phenylmethane sulfonyl fluoride }\end{array}$ \\
\hline
\end{tabular}

Fig 1. FPLC anion exchange chromatography of HPF>12kDa. Biofilm formation (BF) and biofilm destruction (BD) results for the fractions obtained

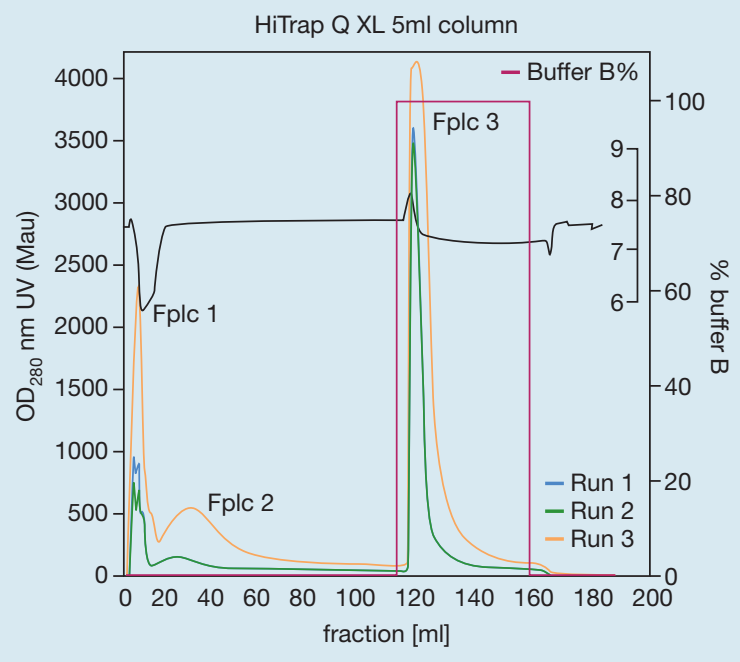

\begin{tabular}{|c|c|c|}
\hline \multirow[t]{2}{*}{ Samples } & \multicolumn{2}{|c|}{ Test results $(\mu \mathrm{g} / \mathrm{ml})$} \\
\hline & BF & BD \\
\hline $\mathrm{HPF}>12 \mathrm{kDa}$ & 18 & 10 \\
\hline Fplc 1 & 6 & 6 \\
\hline Fplc 2 & $\mathrm{NI}$ & NE \\
\hline Fplc 3 & 19 & 11 \\
\hline $\begin{array}{l}\text { NI-no inhibitior } \\
\text { Staphylococcu }\end{array}$ & $\begin{array}{l}\text { e con } \\
\text { oiofilm }\end{array}$ & $\begin{array}{l}\text { no effect over the } \\
\text { ns tested }\end{array}$ \\
\hline
\end{tabular}

from keepers in Costa Rica, these belonged to the Tetragonisca angustula $(\mathrm{n}=36)$ and Melipona beecheii $(\mathrm{n}=21)$ species. The MIC, biofilm formation, and biofilm destruction screening results are presented in Table 1.

Based on the previous results, we decided to carry on activity-guided isolation studies with Tetragonisca angustula honeys. Sample \#29 was selected to carry on activity-guided isolation studies since it presented 
Fig 2. Size exclusion chromatography of Fplc 1 (a). Biofilm formation and biofilm destruction results for the five identified fractions (b). SDS-PAGE results for the fractions obtained (c)

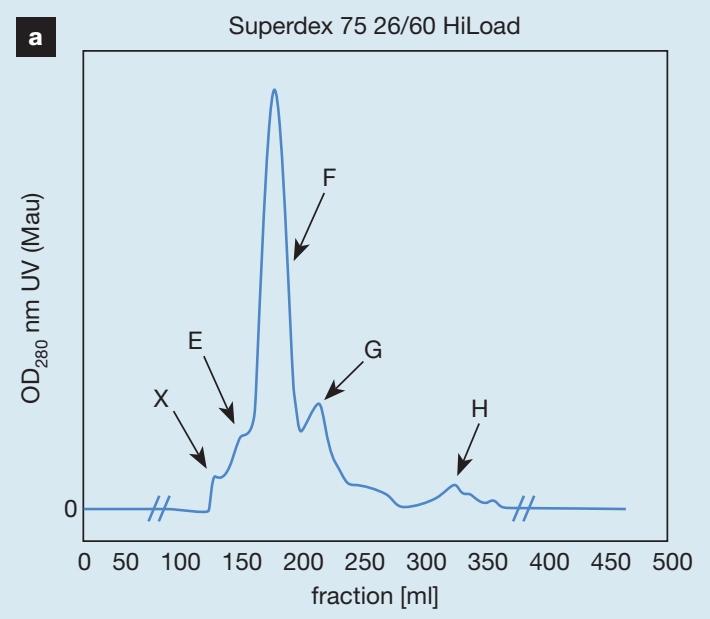

b

\begin{tabular}{|c|c|c|}
\hline Sample & $\begin{array}{l}\text { Biofilm } \\
\text { formation }\end{array}$ & $\begin{array}{l}\text { Biofilm } \\
\text { destruction }\end{array}$ \\
\hline Fplc 1 & $18 \mu \mathrm{g} / \mathrm{ml}$ & $10 \mu \mathrm{g} / \mathrm{ml}$ \\
\hline $\mathrm{X}$ & $\mathrm{NI}$ & NE \\
\hline$E$ & $\mathrm{NI}$ & NE \\
\hline $\mathrm{F}$ & $\mathrm{NI}$ & NE \\
\hline G (TABDF-1) & $11 \mu \mathrm{g} / \mathrm{ml}$ & $11 \mu \mathrm{g} / \mathrm{ml}$ \\
\hline $\mathrm{H}$ & $\mathrm{NI}$ & NE \\
\hline
\end{tabular}

c

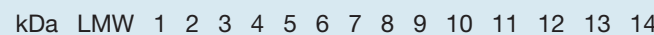

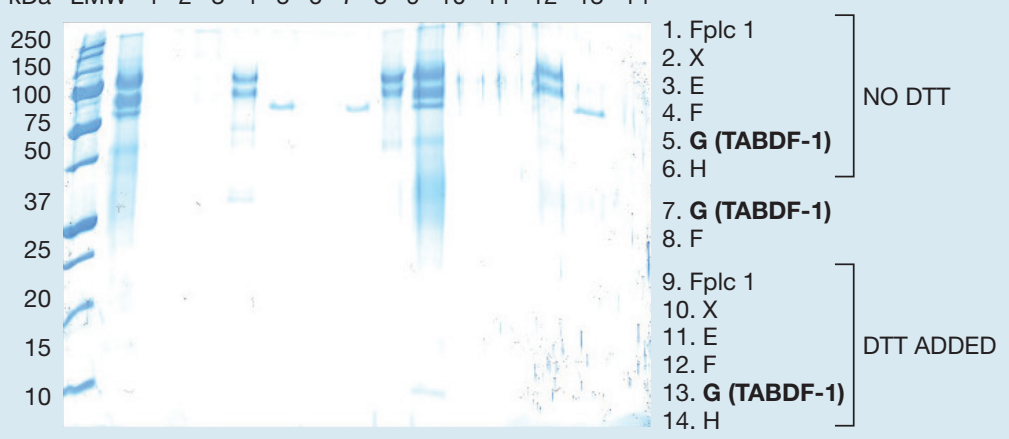

kDa LMW 12

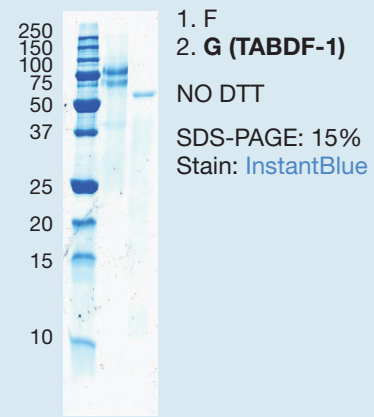

MIC, and biofilm formation and destruction results that were similar to the median values obtained for Tetragonisca angustula honeys. The first step we took was to concentrate organic compounds through Soxhlet extraction. None of the fractions obtained by this method rendered inhibition over Staphylococcus aureus nor had any effect over the biofilm. Consequently, we concentrated the honey proteins through dialysis and tested this fraction in the MIC, biofilm formation, and biofilm destruction assays (Table 2).

It can be inferred that $\mathrm{HPF}>12 \mathrm{kDa}$ had no antimicrobial activity over Staphylococcus aureus. Notwithstanding, HPF $>12 \mathrm{kDa}$ was the source of the inhibition of Staphylococcus aureus biofilm formation and the causing agent of the destruction of a formed Staphylococcus aureus biofilm by Tetragonisca angustula honeys. These antibiofilm features were not due to serine, cysteine or metalloproteases since the protease inhibitors did not alter the effect of HPF $>12 \mathrm{kDa}$ (Table 3).

We performed the MIC test for antibiotics in the presence of $\mathrm{HPF}>12 \mathrm{kDa}$. The concentration of $\mathrm{HPF}>12 \mathrm{kDa}$ was $100 \mu \mathrm{g} / \mathrm{ml}$ since this concentration is close to the $\mathrm{IC}_{100}$ of $\mathrm{HPF}>12 \mathrm{kDa}$ in the biofilm destruction test $(75 \mu \mathrm{g} / \mathrm{ml}$, data not shown). All controls behaved as expected. Under the conditions tested the biofilm was destroyed, leaving Staphylococcus aureus susceptible to the bactericidal activity of the antibiotics. The biofilm destruction effect of $\mathrm{HPF}>12 \mathrm{kDa}$ enabled ampicillin and vancomycin to regain antimicrobial activity over Staphylococcus aureus, the MIC being $4 \mu \mathrm{g} / \mathrm{ml}$ and $63 \mu \mathrm{g} / \mathrm{ml}$ respectively.

\section{Isolation of HPF $>12 \mathrm{kDa}$ antibiofilm constituents}

Using FPLC anion exchange chromatography we obtained two fractions (Fplc 1 and Fplc 3) which displayed the antibiofilm activity (Fig 1). Fraction Fplc 1 was separated by size exclusion chromatography. According to SDS-PAGE, biofilm formation and biofilm destruction tests, this fraction included a protein with a molecular weight of approximately $50 \mathrm{kDa}$ as the main cause of the antibiofilm effect. This protein was named the Tetragonisca angustula biofilm destruction factor one (TABDF-1) (Fig 2).

The size exclusion chromatography of Fplc 3 and the subsequent activity guided isolation revealed a novel constituent with an approximate molecular weight of $75 \mathrm{kDa}$ with antibiofilm properties. This protein was named the Tetragonisca angustula biofilm destruction factor two (TABDF-2) (Fig 3). 
Fig 3. Activity guided isolation of TABDF-2. Size exclusion chromatography of Fplc 3 . Beta amylase (BA), conalbumin (CA), and carbonic anhydrase (CH) as molecular weight markers (a). Biofilm destruction tests performed in every FPLC fraction obtained. The reduction in biofilm absorbance indicates the antibiofilm fractions (b). SDS-PAGE (DDT added) results for the antibiofilm fractions (c). Biofilm formation (BF) and biofilm destruction (BD) assay results for TABDF-2 (d)
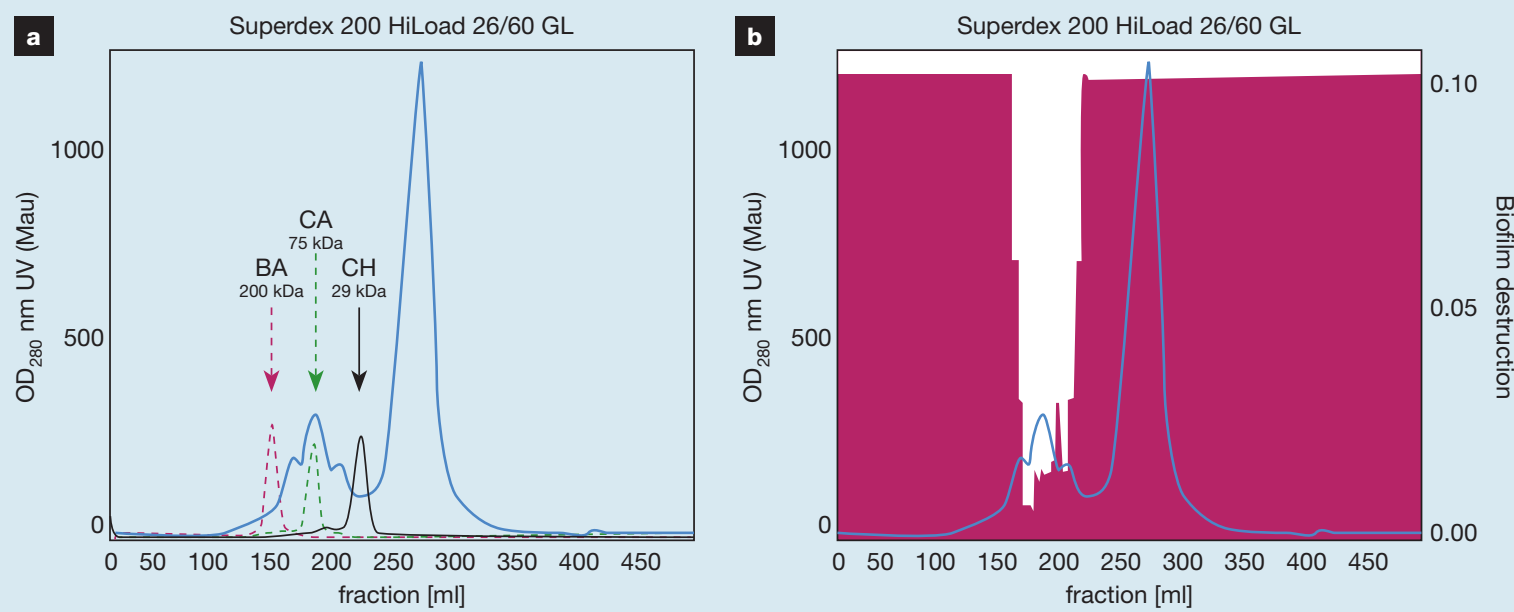

c

kDa LMW $112 \begin{array}{lllllllllllll}3 & 4 & 5 & 6 & 7 & 8 & 9 & 10 & 11 & 12 & 13 & 14\end{array}$

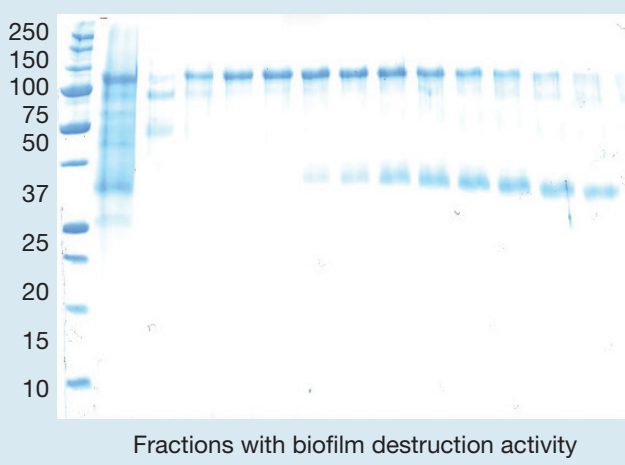

1. FPLC 3

2. Peak 1 fr. $2 A 2$

3. Peak 2 TABDF-2

4. Peak 2 TABDF-2

5. Peak 2 TABDF-2

6. Peak 2 fr. $2 \mathrm{~A} 12$

7. Peak 2 fr. $2 \mathrm{~B} 1$

8. Peak 2 fr. $2 \mathrm{~B} 2$

9. Peak 2 fr. $2 B 3$

10. Peak 2 fr. 2B 4

11. Peak 2 fr. $2 B 5$

12. Peak 2 fr. $2 B 6$

13. Peak 2 fr. $2 \mathrm{~B} 7$

14. Peak 2 fr. $2 B 8$

Fractions with biofilm destruction activity

SDS-PAGE: $15 \%$ DTT ADDED

$\begin{array}{lllllllllllllll}1 & 2 & 3 & 4 & 5 & 6 & 7 & 8 & 9 & 10 & 11 & 12 & 13 & 14 & \text { Stain: InstantBlue }\end{array}$

d

\begin{tabular}{|c|c|c|}
\hline \multirow[t]{2}{*}{ Samples } & \multicolumn{2}{|c|}{$\begin{array}{l}\text { Test results } \\
(\mu \mathrm{g} / \mathrm{ml})\end{array}$} \\
\hline & BF & BD \\
\hline $\mathrm{HPF}>12 \mathrm{kDa}$ & 18 & 10 \\
\hline Fplc 3 & 19 & 11 \\
\hline TABDF-2 & 16 & 16 \\
\hline
\end{tabular}

Fig 4. Amylase activity test results. Amylase activity tests for HPF $>12 k D a$ and the fractions obtained by anion exchange chromatography (a). Amylase activity tests for Fplc 1 and the fractions obtained by size exclusion chromatography (b)

a

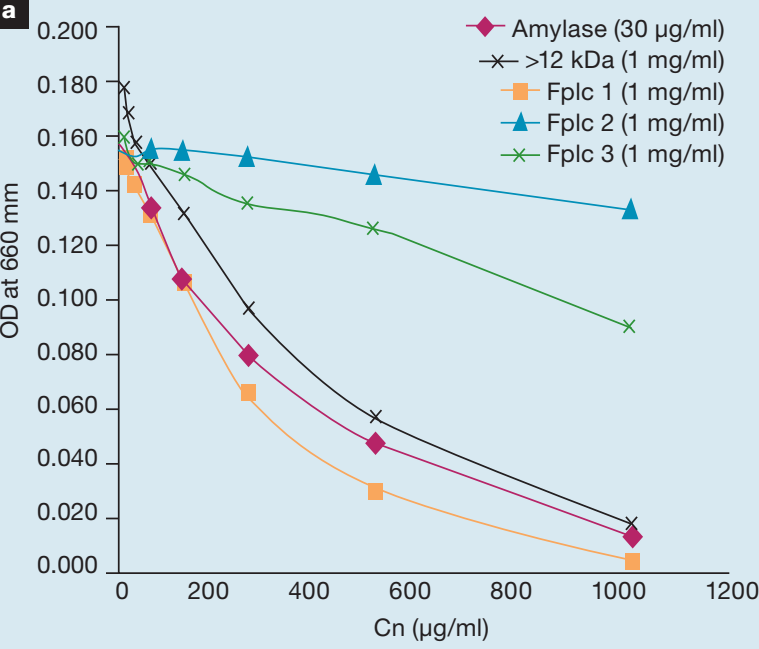

b

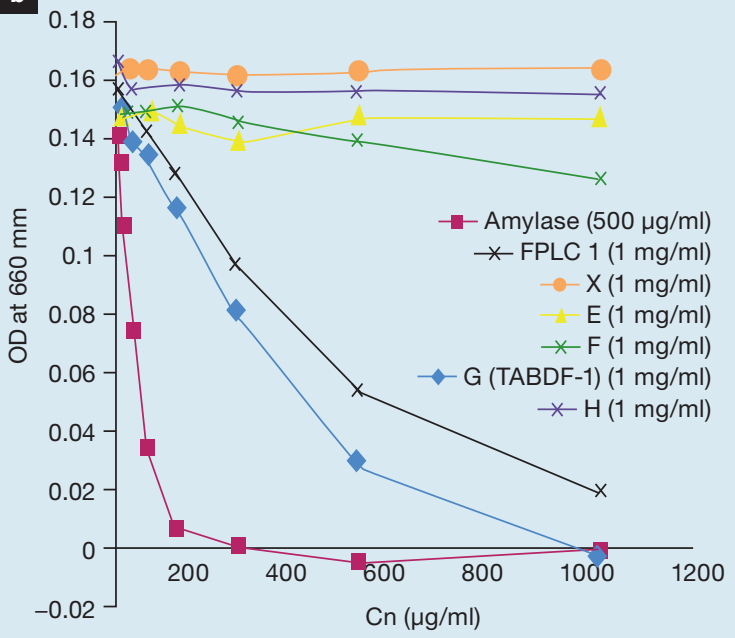
Use for licensed purposes only. No other uses without permission. All rights reserved. 


\section{Enzyme activity}

The majority of amylase activity of Tetragonisca angustula honey was caused by TABDF-1 (Fig 4). DNase activity was only seen at very high concentrations for the fractions that contained the TABDFs (up to $1: 1$ dilution for TABDF-1 and up to 1:10 dilution for TABDF-2). Whereas DNase type 1 remained active in a 1:100000 dilution. In the presence of EDTA, the honey antibiofilm fractions could not degrade DNA. This indicates that all DNase activity present in the TABDFs was metal ion dependent.

\section{Discussion}

Several authors, by different methods, have demonstrated in vitro antibiofilm activity of Medihoney against Staphylococcus aureus and Pseudomonas aeruginosa strains. ${ }^{13,14,33-37}$ Under our testing conditions, Medihoney achieved a MIC and a biofilm formation $\mathrm{IC}_{50}$, but could not cause any disruption to the Staphylococcus aureus biofilm in our biofilm destruction assay. A similar finding was reported by Maddoks et al. ${ }^{34}$ where Medihoney caused extensive death in Staphylococcus aureus, Streptococcus pyogenes, and Pseudomonas aeruginosa biofilms; however, the honey-based wound dressing did not completely remove these established biofilms. As a further matter, our biofilm destruction test was designed to expose complete removal of a biofilm, and to report if such effect is present in a dose dependent fashion by means of an $\mathrm{IC}_{50}$ determination.

The antibiotics tested behaved as has been extensively reported, they were effective against planktonic cells (as shown by our MIC and biofilm formation results), but incapable of causing any inhibitory effect over a Staphylococcus aureus biofilm. 1,7,19,52 Biofilm constitutes a major obstacle for wound healing. $4,7,12,19$ As long as there is biofilm present, the host's immunity will delay healing, and the biofilm will recover via persisting cells in between wound treatments, and antibiotic therapy. ${ }^{2,7,15}$ It would be beneficial to the wound treatment to use antibiofilm agents that can remove biofilms. ${ }^{6}$

We found that Tetragonisca angustula honeys from Costa Rica can inhibit the planktonic growth, the biofilm formation, and are capable of destroying a Staphylococcus aureus biofilm. All of these effects are performed in a concentration-dependent manner. The antibiofilm effect is present in the protein fraction of Tetragonisca angustula honeys. The same set of Meliponini honey samples that were used in the present investigation had their botanical origin determined (up to species level) in a previous study by Zamora et al. ${ }^{23}$ There are seven botanical species which comprised the main nectar sources of the Tetragonisca angustula honeys; five of them are shared with Melipona beecheii honeys. ${ }^{23}$ The protein nature of the antibiofilm factors, and the melissopalynology results imply that the antibiofilm properties of Tetragonisca angustula honeys are of bee origin.

The protein fraction of Tetragonisca angustula honeys (HPF $>12 \mathrm{kDa})$ has no antimicrobial activity over Staphylococcus aureus planktonic cells. Nevertheless, its antibiofilm action allowed ampicillin to regain antimicrobial activity and vancomycin to recover its MIC value over a Staphylococcus aureus biofilm. This result suggests that the Tetragonisca angustula biofilm destruction factors disrupt the Staphylococcus aureus biofilm EPS matrix in an extensive manner; thus allowing exposure of cells embedded in the biofilm matrix to antibiotics. This finding along with the antimicrobial activity, antioxidant capacity and immunomodulatory activities previously reported for Tetragonisca angustula honeys $9,23,44-46$ demonstrate that this type of honeys could act along with antibiotics in antibiofilm wound healing therapies.

The antibiofilm proteins of Tetragonisca angustula do not have serine, cysteine or metalloprotease activity, and could only cleave DNA at high concentrations compared with DNase I. We hypothesise that the TABDFs have as targets polymer constituents of the EPS matrix of the Staphylococcus aureus biofilm, since the damage of the matrix polymers could disrupt the cohesiveness of the biofilm, and consequently destroy the biofilm structure. ${ }^{17}$

According to our results, TABDF-1 is a monomeric protein of approximately $50 \mathrm{kDa}$ that is responsible of the amylase activity of Tetragonisca angustula honeys. In the biofilm destruction assay we tested five Apis mellifera honeys that expressed higher diastase (bee amylase) activity than the Tetragonisca angustula honeys of the present study. The Apis mellifera honeys yielded no biofilm destruction activity (data not shown). Our findings suggest that TABDF-1 may present structural differences to bee amylase that could explain its biofilm destruction activity. TABDF-2 is a protein monomer of approximately $75 \mathrm{kDa}$. Although its target in the Staphylococcus aureus EPS biofilm matrix remains unknown, our data suggests that TABDF-2 should possess a mechanism of action over the Staphylococcus aureus biofilm different to TABDF-1.

\section{Conclusion}

Costa Rican Tetragonisca angustula honeys are capable of destroying an Staphylococcus aureus biofilm, via two proteins with the antibiofilm properties, TABDF-1 and TABDF-2. These proteins, most probably are of bee origin. The biofilm destruction factors of Tetragonisca angustula honey allowed ampicillin and vancomycin to recover their antimicrobial activity over a Staphylococcus aureus biofilm. Investigations of the sequence of the TABDFs and the proper identification of their targets inside the Staphylococcus aureus biofilm matrix are needed.

The antibiofilm effect we are reporting herein, makes Costa Rican Tetragonisca angustula honey a promising candidate for research and development of novel wound dressings focused on the treatment of acute and chronic Staphylococcus aureus biofilm wound infections. Jwc

\section{Acknowledgements}

We would like to thank the following organisations for their financial support: O \& O Office of Utrecht University and the Scholarships Office of Universidad Nacional of Costa Rica. We also acknowledge Piet Aerts for his technical assistance with the FPLC fractionations. 


\section{References}

1 Costerton, J.W., Stewart, P. S., Greenberg, E. P. Bacterial biofilms: a common cause of persistent infections. Science 1999; 284: 5418, 1318-1322.

2 Precival, S.L., Cutting, K.F. Biofilms: possible strategies for suppression in chronic wounds. Nurs Stand 2009; 23: 32, 64-72. 3 Percival, S.L., Hill, K.E., Malic, S. et al. Antimicrobial tolerance and the significance of persister cells in recalcitrant chronic wound biofilms. Wound Repair Regen 2011; 19: 1, 1-9.

4 Davis, S.C., Martinez, L., Kirsner, $R$. The diabetic foot: the importance of biofilms and wound bed preparation. Curr Diab Rep 2006; 6 : $6,439-445$.

5 Thomas, J.G., Rampage, G., Lopez-Robot, J.L. Biofilms and implant infections. In: Ghannoum, M., O'Toole, G.A. (eds). Microbial biofilms. ASM Press, 2004. 6 Wolcott, R.D., Rhoads, D.D. A study of biofilm-based wound management in subjects with critical limb ischaemia. J Wound Care 2008; 17: 4, 145-155. 7 Percival, S.L., Hill, K.E., Malic, S. et al. Antimicrobial tolerance and the significance of persister cells in recalcitrant chronic wound biofilms. Wound Repair Regen 2011; 19: 1 , 1-9.

8 Wolcott, R.D., Rhoads, D.D., Dowd, S.E. Biofilm and chronic wound inflammation. J Wound Care 2008; 17: 8, 333-341.

9 Zamora, L.G., Beukelman, K., van den Berg, B. et al. The antioxidant and immunomodulatory activity of stingless bee honeys proceeding from Costa Rica. Oxid Antioxid Med Sci 2015; 4: 1, 49-55.

10 Høiby, N., Fomsgaard, A., Tvenstrup Jensen, E. et al. The immune response to bacteria biofilms. In: Lappin-Scott, H. M., Costerton, J. W. (eds). Microbia biofilms. Cambridge University Press, 1995.

11 Bjarnsholt, T., Kirketerp-Møller, K., Jensen, P.Ø. et al. Why chronic wounds will not heal: a novel hypothesis. Wound Repair Regen 2008; 16: 1, 2-10.

12 Brown, M.R.W., Smith, A.W. Antimicrobial agents and biofilms. In: Wilson, M., Devine, D. (eds). Medical implications of biofilms. Cambridge University Press, 2003. 13 Campeau, M.E.M., Patel, R. Antimicrobial activity of manuka honey in combination with antibiotics. Int J Bacteriol 2014; article ID 795281. http://dx.doi. org/10.1155/2014/795281

14 Lui, M., Lu, J., Müller, P. et al. Antibiotic-specific differences in the response of Staphylococcus aureus to treatment with antimicrobials combined with manuka honey. Front Microbiol 2015; 5, 779. doi: 10.3389/fmicb.2014.00779 15 Stewart, P.S., Mukherjee, P. K. Ghannoum, M.A. Biofilm antimicrobial resistance. In: Ghannoum, M., O'Toole, G. A. (eds). Microbial biofilms. ASM Press, 2004.

16 Flanders, J.R., Yildiz, F.H. Biofilms as reservoirs for disease. In: Ghannoum, M., O'Toole, G. A (eds). Microbial biofilms. ASM Press, 2004.

17 Branding, M.G., Jass, J., Lappin-Scott, H.M. Dynamics of bacterial biofilm formation. In: Lappin-Scott, H. M., Costerton, J. W. (eds). Microbial biofilms. Cambridge University Press, 1995. 18 Ebrey, R., Hamilton, M.S., Cairns, G., Lappin-Scott, H.M. Biofilms and hospital-acquired infections. In: Ghannoum, M., O'Toole, G. A. (eds). Microbial biofilms. ASM Press, 2004. 19 Ehrlich, G.D., Hu, F.Z., Post, J.C. Role for biofilms in infectious diseases. In: Ghannoum, M. O'Toole, G. A. (eds). Microbial biofilms. ASM Press, 2004.

20 James, G.A., Swogger, E., Wolcott, R. et al. Biofilms in chronic wounds. Wound Repair Regen 2008; 16: 1, 37-44 doi:

10.1111/j.1524-475X.2007.00321.x $21 \mathrm{Kim}$, P.J., Steinberg, J.S. Wound care: biofilm and its impact on the latest treatment modalities for ulcerations of the diabetic foot. Semin Vasc Surg 2012; 25: 2 , 70-74. doi: 10.1053/j semvascsurg.2012.04.008 22 Oryan, A., Zaker, S.R. Effects of topical application of honey on cutaneous wound healing in rabbits. Zentralbl Veterinarmed A. 1998; 45 : 3, 181-188.

23 Zamora, G., Beukelman, K., van den Berg, B et al. The antimicrobial activity and microbiological safety of stingless bee honeys from Costa Rica. J Apic Res 2014; 53: 5 503-513. http://dx.doi.org/10.3896/ IBRA.1.53.5.04

24 Cooper, R.A. The modern use of honey in the treatment of wounds. Bee World 2005; 86: 4, 110-113. http://dx.doi.org/10.1080/00057 72X.2005.11417325

25 Molan, P.C. The evidence supporting the use of honey as a wound dressing. Int J Low Extrem Wounds 2006; 5: 1, 40-54. doi: 10.1177/1534734605286014

26 Boateng, J., Catanzano, O. Advance therapeutic dressings for effective wound healing - a review. J Pharm Sci 2015; 104: 11, 3653-3680. doi: 10.1002/jps.24610 27 Oryan, A., Alemzadeh, E., Moshiri, A. Biological properties and therapeutic activities of honey in wound healing: a narrative review and meta-analysis. J Tissue Viability 2016; 25: 2, 98-118. doi: 10.1016/j. jtv.2015.12.002

28 Willix, D.J., Molan, P.C., Harfoot, C.G. A comparison of the sensitivity of wound infecting species of bacteria to the antibacterial activity of manuka honey and other honey. J Appl Bacteriol 1992; 73: 5
388-389.

29 Cooper, R.A., Halas, E., Molan, P.C. The efficacy of honey in inhibiting strains of Pseudomonas aeruginosa from infected burns. J

Burn Care Rehabil 2002; 23: 6, 366-370. doi: 10.1097/01. BCR.0000036453.98917.41

30 Stephens, J.M.C., Molan, P.C. Clarkson, B.D. A review of eptospermum scoparium

(Myrtaceae) in New Zealand. N Z J Bot 2005; 43, 431-449.

31 Simon, A., Sofka, K.,

Wiszniewsky, G. et al. Wound care with antibacterial honey (Medihoney) in pediatric haematology-oncology. Support Care Cancer 2006; 14: 1, 91-97. doi: 10.1007/s00520-005-0874-8 32 Federal Drug Administration (2008) Summary for Derma Sciences OTC APIMED, Medihoney Primary and Medihoney $100 \%$ honey dressings with active Manuka honey. https://tinyurl.com/ jbbwn69 (accessed 16 March 2017)

33 Merckoll, P., Jonassen, T.Ø. Vad, M.E. et al. Bacteria, biofilm and honey: a study of the effects of honey on 'planktonic' and biofilm-embedded chronic wound bacteria. Scand J Infect Dis 2009; 41: 5, 341-347. doi:

$10.1080 / 00365540902849383$

34 Maddoks, S.E., Jenkins, R. E., Rowlands, R.S. et al. Manuka honey inhibits adhesion and invasion of medically important wound bacteria in vitro. Future Microbiol 2013; 8: 12, 1523-1536. doi: 10.2217/ fmb. 13.126

35 Lu. J., Turnbull, L., Burke, C.M. et al. Manuka-type honeys can eradicate biofilms produced by Staphylococcus aureus strains with different biofilm-forming abilities. PeerJ 2014; 2: e326. doi 10.7717/ peerj.326

36 Cooper, R., Jenkins, L., Hooper, $\mathrm{S}$. Inhibition of biofilms of Pseudomonas aeruginosa by Medihoney in vitro. J Wound Care 2014; 23: 3, 93-104. doi: 10.12968/ jowc.2014.23.3.93

37 Halstead, FD. Webber M. A. Rauf, M. et al. In vitro activity of an engineered honey, medical-grade honeys, and antimicrobial wound dressings against biofilm-producing clinical bacterial isolates. J Wound Care 2016; 25: 2, 93-102. doi: 10.12968/jowc.2016.25.2.93 38 Kent, R.B. Mesoamerican stingless bees. J Cult Geogr 1984; 4: 2, 14-28. http://dx.doi. org/10.1080/08873638409478571 $39 \mathrm{De}$ Jong, $\mathrm{H}$. The land of corn and honey. The keeping of stingless bees (meliponiculture) in the ethno-ecological environment of Yucatán (Mexico) and El Salvador. $\mathrm{PhD}$. Thesis, Utrecht University, 1999.

40 Cortopassi-Laurino, M. Imperatriz-Fonseca, V.L., Roubik, D.W. et al Globeliponiculture:

challenges and opportunities. Apidologie 2006; 37: 2, 275-292. 41 Vail, G. The maya codices. Annu Rev Anthropol 2006; 35, 497-519. doi:10.1146/annurev. anthro.35.081705.123324 42 Vit, P., Medina, M., Enríquez, M.E. Quality standards for the medicinal use of Meliponinae honey in Guatemala, Mexico and Venezuela. Bee World 2004; 85: 1 , 2-5. http://dx.doi.org/10.1080/0005 772X.2004.11099603

43 Aguilar, I., Herrera, E., Zamora, L.G. Stingless bees of Costa Rica. In Vit, P., Pedro, S.R.M., Roubik, D. (eds). Pot honey: a legacy of stingless bees. Springer, 2013. 44 Zamora, L.G., Halkes, S.B.A. Beukelman, C.J. et al. Antibacteriële activiteit van de honing van angelloze bijen uit Costa Rica. [Antibacterial activity of stingless bee honey from Costa Rica] [In Dutch] Netherlands Tijdschrift voor Fytotherapie 2011; 3, 16-18. 45. Zamora, L.G., Arias, M.L. Aguilar, I., Umaña, E. Costa Rican pot-honey: its medicinal use and antibacterial effect. In Vit, P., Pedro, S.R.M., Roubik, D. (eds). Pot honey: a legacy of stingless bees. Springer, 2013.

46 Zamora, L. G., Arias, M. L. [Microbiological quality and antimicrobial activity of honey coming from stingless bees] [in Spanish] Rev Bioméd. 2011; 22: 2, 59-66.

47 Zamora, L.G., Beukelman, C. J., van den Berg, A.J.J. et al. Stingless bee honeys from Costa Rica exhibit antimicrobial activity against antibiotic-resistant clinical isolates. J Biol Activ Prod Natur 2015; 5: 2 144-149. http://dx.doi.org/10.1080/ 22311866.2015.1053099

48 Hensen, S.M. Bovine

Staphylococcus aureus mastitis: bacterial adhesion and invasion in relation to pathogenesis and antimicrobial sensitivity. $\mathrm{PhD}$. thesis. Utrecht University, 2000

49 Bardoel, B. W., Vos, R., Bouman, T. et al. Evasion of Toll-like receptor 2 activation by 